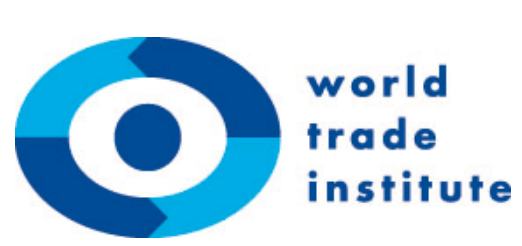

\title{
Making use of TRIPS flexibilities: Implementation and diffusion of compulsory licensing regimes in Brazil and India
}

\author{
Omar Serrano, University of Geneva \\ Mira Burri, University of Bern
}

As their economic clout increases, emerging powers are becoming policy-shapers in their own right. This chapter evaluates the ways in which emerging countries have made use of the flexibilities available under the TRIPS Agreement to espouse their social and economic concerns. We consider one of the most significant and controversial of these flexibilities: compulsory licensing as a tool for providing access to essential medicines. Our analysis focuses on India and Brazil as the two most vocal actors on the international scene opposing strong intellectual property (IP) protection. It compares Brazil and India's patterns of domestic implementation so as to gain a more granular understanding of the law and practice of compulsory licensing in these countries. A further aim of the chapter is to determine whether coordination, learning or emulation has taken place between these countries. If it has, does it explain the diffusion of compulsory licensing practices and, if not, what has led to the particular implementation design chosen? The results are somewhat puzzling, but all the more interesting as they reveal that India and Brazil, despite their shared IP strategies at the international level, have chosen different TRIPS implementation paths domestically. We find no evidence of coordination but of processes of learning and emulation taking place.

\footnotetext{
This paper was written in the context of a project financed by the Swiss Network for International Studies (SNIS), the Swiss National Science Foundation (SNF) and the Brazilian-Swiss Joint Research Programme (BSJRP). Funding by the SNF, SNIS, and BSJRP is gratefully acknowledged. Research for this paper was partially conducted at the World Trade Institute of the University of Bern, Switzerland.
}

WTI working papers are preliminary documents posted on the WTI website (www.wti.org) and widely circulated to stimulate discussion and critical comment. These papers have not been formally edited. Citations should refer to a "WTI Working Paper", with appropriate reference made to the author(s). 


\section{Making use of TRIPS flexibilities: implementation and diffusion of compulsory licensing regimes in Brazil and India}

\section{Introduction}

Global public health is one of the areas in which emerging countries have taken a critical role in shaping international rules. As early on as the Uruguay Round Negotiations, which ultimately led to the adoption of the Agreement on Trade-related Aspects of Intellectual Property Rights (TRIPS) ${ }^{1}$ as part of the World Trade Organization (WTO), Brazil and India assumed a leading role in opposing stronger intellectual property (IP) protection. Ultimately, these countries only acquiesced because of the pressures of the WTO single undertaking and the inherent bargains that linked IP protection to improved market access for textiles and agriculture (Deere Birkbeck 2008). Post-TRIPS, India and particularly Brazil, have continued to lead coalitions of developing countries with the aim of limiting and calibrating the impact of the changes brought about by the TRIPS Agreement.

These efforts have involved launching agendas on diverse development issues such as: access to medicines, the linkage between human rights and health, protection of traditional knowledge and access to biological resources (Kapczynski 2008). These initiatives have been taken up in different international venues, among them the WTO, the World Intellectual Property Organization (WIPO), the World Health Organization (WHO) and the Convention on Biological Diversity (CBD). As we discuss later on, Brazil and India have been especially successful in transforming the norms governing global health, thus establishing one of the few areas in which it is possible to observe real rule shaping by emerging actors.

Not all emerging countries have taken the same approach. While on the surface it is opposed to Western-dominated IP regimes, China "has been reluctant to press for a structural reform of intellectual property rights regulation in the WTO, despite lending its support to developing countries when the negotiations over the Decision on Implementation of Paragraph 6 of the Doha Declaration were under way" (Chan 2010: 115). Thus, while nominally in favour of these initiatives, China has pursued a less contentious approach. Other emerging economies, such as Mexico, have distanced themselves from these international efforts, seeking to act as mediators between industrialized and industrializing countries. This position has proved hard to maintain and even led to a heated exchange between the Brazilian, Argentinian and Mexican delegates during the launching of the WIPO Development Agenda (see WIPO IIM/1/6 PROV.2). ${ }^{2}$

Given their salience, multilateral efforts by developing countries towards ensuring a balanced interpretation of TRIPS are well documented (Drahos 1997; Correa 2000; Sykes 2000; Panagariya 2002; Bass 2002/2003; Wade 2003; Helfer 2004; Yu 2004; Kapczynski 2008). Domestic efforts complementing and supporting these international initiatives have received much less attention. One notable exception is Birkbeck's (2008) work on TRIPS' implementation by developing countries. That the countries leading multilateral efforts towards shaping the global health regime, mainly Brazil and India, have also been enacting domestic legislation seeking to maximize flexibilities under TRIPS is an interesting empirical observation. Rule shaping can be a result of multilateral initiatives, but it may also result from norm evolution through domestic practice and institutional adaptation. We suggest that the interaction between the international and the national level needs to be further explored, so that we can understand why and how policies are enacted and implemented.

\footnotetext{
${ }^{1}$ Agreement on Trade Related Aspects of Intellectual Property Rights, 15 April 1994, 33 I.L.M. 81 (1994) [hereinafter cited as TRIPS or the TRIPS Agreement].

${ }^{2}$ http://www.wipo.int/meetings/en/doc_details.jsp?doc_id=44609 (last accessed 15 March 2016).
} 
This chapter looks into one of the most salient domestic practices and its evolution in the post-TRIPS environment - that of compulsory licensing in the two emerging countries that were the most vocal during the TRIPS negotiations. In so doing, it seeks to ascertain the extent to which these two countries have learnt from or emulated each other's experiences and whether coordination towards implementing flexibilities has taken place. The chapter first provides an overview of compulsory licensing norms looking at their origin and evolution, which is an important aspect for consideration, as matters in this context cannot simply be labelled as good or bad, pro- or counter-development. The second section looks at whether learning, emulation or coordination has taken place in the domestic implementation of compulsory licensing norms. The third section provides an explanation for the significant differences in the implementation of compulsory licensing norms by Brazil and India. Finally, the conclusion summarizes the main findings in terms of both the motivation for and the diffusion of particular compulsory licensing policies.

\section{Origins and evolution of compulsory licensing norms}

Compulsory licensing is in fact an old construct of international IP law, which has existed ever since the 1883 Paris Convention. ${ }^{3}$ It reflects the fundamental idea that IP rights are not absolute, and that there are situations that demand the use of certain IP rights without the consent of the rights-holder, in particular for the protection of key public interests. While the TRIPS Agreement heightened and harmonized the standards of international patent protection, and was clearly a success for IP-based industries (Sell 2003; Helfer 2004), including the pharmaceutical industry, in fact it strengthened rather than weakened the compulsory licensing regime (Reichman/Hasendahl 2003). In effect, developing countries, including those with pharmaceutical production capabilities such as India and Brazil, could no longer reverse-engineer patented products, as their domestic laws had to be made TRIPS-compliant by 2005. They could, however, use the flexibility permitted under Article 31 TRIPS on compulsory licensing. This TRIPS provision is fairly openly formulated and allows governments to grant compulsory licences on various grounds, including public interest, anti-competitive conduct or for non-commercial government use. While there are certain conditions attached, such as a duty to notify and to negotiate with the affected patentees, even these specific requirements can be waived in cases of "national emergency or other circumstances of extreme urgency or in cases of public noncommercial use" (Article 31(b) TRIPS). This outcome can be interpreted as a victory for the developing countries, which were ably represented by the Indian delegation during the Uruguay negotiations (Watal 2002: 33-44; Watal 2015: 295-320) and managed to counterbalance the aggressive IP industries' lobbying and the strong positions of industrialized countries. On the other hand, this victory can also be deemed relatively modest when compared to the rest of the TRIPS obligations, which are far-reaching and onerous. It should also be stressed that although, in principle, developing countries could use compulsory licensing, in reality many of these countries lacked the capacity to manufacture the drugs. It is critical in this regard to understand that although Article 31 TRIPS was broad in scope and fairly open in the justifications for compulsory licensing, Article 31(f) expressly required products manufactured under a compulsory licence to serve "predominantly for the supply of the domestic market" and in effect limited exports to $49.9 \%$ of the total output.

This situation, which, in reality, restricted the protection of vital public health interests of developing countries and was accompanied by the rather inimical behaviour of major pharmaceutical companies, came to a halt in 2001. At that time, developing country members of the WTO made the removal of the existing constraints on public health policies an essential element of the deal to launch the new, Doha round of trade negotiations. The political moment was opportune and the

\footnotetext{
${ }^{3}$ Paris Convention for the Protection of Industrial Property, 20 March 1883, as revised at Stockholm (1967), 21 UST 1583, 828 UNTS 305 [hereinafter the Paris Convention].
} 
Doha Ministerial Declaration on the TRIPS Agreement and Public Health ${ }^{4}$ of 2001 was a significant breakthrough. The Declaration affirmed that the TRIPS Agreement "can and should be interpreted and implemented in a manner supportive of WTO Members' rights to protect public health and, in particular, to promote access to medicines for all" (para. 4). The Doha Declaration went on to reaffirm the key flexibilities available under the TRIPS Agreement, such as the power of WTO Members "to grant compulsory licences and the freedom to determine the grounds upon which such licences are granted", as well as "the right to determine what constitutes a national emergency or other circumstances of extreme urgency" (para. 3, lit. b and c). The Doha Declaration also addressed the constraints on exports set out in Article 31(f) TRIPS and instructed the Council for TRIPS "to find an expeditious solution to this problem" (para. 6).

The scheme that was ultimately negotiated under this mandate envisioned a process of back-to-back compulsory licences that would enable any country that needs medicines at lower prices than those charged by local patentees to seek assistance from other countries able and willing to produce the drugs for export purposes, without interference from the patentee in either country. ${ }^{5}$ This solution was not agreed upon without a fight and was reached only after long and difficult negotiations. It was initially embodied in a Waiver, known as the Decision of 30 August 2003 or the Paragraph 6 Decision. ${ }^{6}$ The Waiver will become permanent when enough countries (two thirds of the WTO membership) sign the pending Amendment to the TRIPS Agreement, which would add Article 31bis to the legal text. The ratification process has been protracted and the WTO General Council decision of 30 November 2015 had to yet again extend the deadline to 31 December 2017. ${ }^{7}$ Until then the Waiver remains in effect.

Overall, the Doha Declaration and the 2003 Waiver decision contributed greatly to confirming the flexibilities under TRIPS and clarified the legal situation as to their use for public health purposes. Although the solution found is not optimal and was again in many respects shaped by the industrialized countries' interests in protecting the investment of pharmaceutical companies (Abbott/Reichman 2007), it still provided a solid basis for the use of compulsory licensing to ensure the availability and accessibility of life-saving drugs for poor people. Interestingly, despite this evolution of the norm and the room for action created, there was no immediate use of compulsory licensing.

It was only as of 2006 that a practice of compulsory licensing of pharmaceuticals became visible and globally spread. At that time, Thailand issued two compulsory licences for AIDS drugs and one for a cardiovascular drug. In 2007, Brazil issued a compulsory licence for government use of Merck's patent on an antiretroviral drug. Other compulsory licensing procedures that led to agreements with major pharmaceutical companies were reportedly initiated in Malaysia (2004), Indonesia (2004), Brazil (2003 and 2007), Zambia (2004), Zimbabwe (2004) and Mozambique (2004) (for an overview, see Reichman 2009; Beall/Kuhn 2012). India's first compulsory licence was not issued until 2012. This was for the chemotherapy drug sorafenib, sold by Bayer \& Co. under the trademark Nexavar ${ }^{\circledast}$ (Thomas 2014). Natco Pharma Ltd., an Indian generic firm, was awarded the licence; it was required to pay a royalty at the rate of $6 \%$ of net sales of the drug to Bayer. ${ }^{8}$ Very often the threat of

\footnotetext{
${ }^{4}$ World Trade Organization, Declaration on the TRIPS Agreement and Public Health, 20 November 2001, WT/MIN(01)/DEC/2 [hereinafter the Doha Declaration].

${ }^{5}$ For a detailed analysis of the legal mechanisms, see Matthews 2004; Abbott/Reichman 2007.

${ }^{6}$ World Trade Organization, Implementation of Paragraph 6 of the Doha Declaration on the TRIPS Agreement and Public Health, Decision of the General Council of 30 August 2003, WT/L/540, 30 August 2003.

${ }^{7}$ WTO General Council, Amendment of the TRIPS Agreement - Fifth Extension of the Period for the Acceptance by Members of the Protocol Amending the TRIPS Agreement, WT/L/965, 2 December 2015.

${ }^{8}$ The Intellectual Property Appellate Board of India upheld the Controller's decision on 4 March 2013, although it increased the royalty owed to Bayer from $6 \%$ to $7 \%$.
} 
compulsory licensing sufficed to trigger deals with pharmaceutical companies and a subsequent lowering of prices (e.g. Abbott/Reichman 2007; Cohen 2007; Love 2007; Reichman 2009). It should be noted that none of these cases made use of the special regime under the Waiver but rather utilized the conventional path under Article 31 TRIPS. In 2007, Rwanda was the first country to actually make use of the Waiver through a compulsory licence for AIDS drugs, seeking assistance from Canada (Goodwin 2008). This approach was not particularly efficient, as the procedures in Canada were fairly cumbersome and lengthy (Lybecker/Fowler 2009). Rwanda's case is still the only precedent.

To understand this late and sporadic use of compulsory licensing, we need to contextualize it against the backdrop of the different pressures exerted by the industrialized countries, the pharmaceutical industry in both developing and developed countries, and local and global civil society organizations. It must also be seen in the context of the idiosyncratic implementation practices in different countries, each of which has their own set of economic, political and social considerations. It is also important to note that the institution of compulsory licensing as a tool of IP policy is contentious. Its use could potentially trigger a number of effects, which may work to the detriment rather than the benefit of developing nations in their attempts to secure cheaper medicines for their populations (e.g. Bird 2009; Reichman 2009). Compulsory licensing is also one tool among many that governments may want to consider when implementing their public health policies (e.g. Kapczynski 2009), and while singling out this legal instrument, we too need to be careful to frame it within the larger policy toolbox.

Some important pressures are exerted through avenues other that the WTO, in particular through preferential trade agreements (PTAs). While this topic is beyond the analytical focus of this chapter, it should be noted that many of the flexibilities concerning governmental powers to grant compulsory licences for patented pharmaceuticals, as well as other policy space presently available under TRIPS may be severely limited by the one-sided IP provisions of some PTAs. In particular, the US has effectively mobilized its legal apparatus and bargaining power to seize back some of the lost ground with regard to pharmaceutical patents. As well as "ratcheting up" of IP protection (including in particular: extension of the scope of patentability; limits on patent revocation; patent term extension; prohibition of parallel importation; linkage between patent status and regulatory approval; limitations on compulsory licensing; extended data protection and data exclusivity, and obligatory accession to other multilateral IP agreements, such as the Patent Cooperation Treaty), the US is attempting to directly influence and constrain the pharmaceutical coverage programmes of its trading partners (Lopert/Gleeson 2013). This campaign is accompanied by considerable political pressure from the US Trade Representative (USTR) and other governmental agencies, as well as from individual pharmaceutical companies with economic clout. This pressure has a strong impact upon the political environment as a whole and also on the choice and timing of the concrete measures taken (Mercurio 2006: 215-238; Abbott/Reichman 2007: 958-966; Dwyer 2007; Reichman 2007; Lopert/Gleeson 2013). At the multilateral level, pressure is exerted through the WIPO Standing Committee on the Law of Patents and the concerted efforts of OECD countries in this venue to reach agreement on a Substantive Patent Law Treaty (SPLT). The SPLT seeks deeper harmonization of the rules concerning the drafting, filing and examination of patent applications, as well as of the requirements for patentability. Reichman and Cooper Dreyfuss (2007) have argued that, if adopted, the SPLT is likely, yet again, to erode existing flexibilities under the TRIPS Agreement and preclude "virtually every pro-competitive option still left open - from exceptions to patentability, limitations on exclusive rights, and the possibility of imposing compulsory licenses" (Abbott/Reichman 2007: 961).

This combined pressure should not be underestimated and may have been one of the reasons for the relatively late start of the compulsory licensing practice. Another critical contextualizing factor 
relates to the different implementation strategies chosen by different countries, which have been determined by the interplay of domestic economic, political and social forces, as well as by the particular characteristics of the state (Yeung 2005; Eimer/Lütz 2010). These particularities raise questions concerning the feasibility of policy diffusion between emerging countries. The next section looks in detail at the kind of processes whereby policies diffuse, thus providing an analytical framework to evaluate whether and how the diffusion of compulsory licensing has taken place.

\section{Diffusion processes and compulsory licensing}

The late and cautious use of compulsory licensing is noteworthy, given that by 2005 the transition periods given to most developing countries to make their patent legislation TRIPS-compatible had already expired. ${ }^{9}$ Compulsory licensing, despite generating an intense backlash from multinationals based in industrialized countries has been followed by what appears to be a cascade of similar efforts by emerging economies, including Brazil and India (see Beall/Kuhn 2012). This curious timing poses an interesting question, namely whether there has been coordination of domestic initiatives aimed at preserving TRIPS flexibilities between emerging countries, or whether less institutionalized and subtler diffusion processes may be taking place. Given that emerging countries have formed coalitions on IP-related issues at international organizations, and have even created specific fora, such as the India-Brazil-South Africa Dialogue Forum (IBSA), ${ }^{10}$ it is conceivable that policies diffuse through such venues. On the other hand, civil society organizations and epistemic communities have been vocal and heavily involved in furthering access to health initiatives - so, they too may have played a role.

Policy transfer and diffusion processes have received much scholarly attention in recent years (Simmons/Dobbin/Garret 2006; Keohane 2009; Marsh/Sharman 2009; Gilardi 2012). At the most basic level, international diffusion takes place when government policy decisions are conditioned by prior policy choices in other countries (Simmons/Dobbin/Garrett 2006). Taking this broad conceptualization, and considering the timing of the enactment of compulsory licensing, it seems plausible that decisions taken by governments on compulsory licensing were conditioned by prior policy choices in other jurisdictions. However, this does not explain the mechanisms through which policy diffusion may take place. Gilardi (2012) argues that diffusion needs to be conceived as a process (and not an outcome) which does not necessarily lead to convergence. While convergence considers the end effect (how many countries have adopted a given policy), diffusion looks at the process whereby a pattern of adoption is established. There are several mechanisms by which diffusion may take place: coercion, competition, learning and emulation. Coercion usually involves some form of conditionality and often relies on market power; while competition derives from economic rivalry (e.g. in cases where policies implemented by a third party may entail losing market share). Learning and emulation are more cooperative mechanisms; the main difference between them is that learning follows instrumental purposes, whereas emulation is normative (as discussed further below). Neither coercion nor competition seem adequate explanations for the diffusion of compulsory licensing in the two cases analysed in this chapter (Brazil and India), as power asymmetries and economic competition between these countries are largely absent in the relevant field (pharmaceuticals). The focus of the analysis is therefore on learning and emulation processes.

\footnotetext{
${ }^{9}$ As of 2005 , developing countries have been required to provide at least 20 years of patent protection to a broad range of products, including pharmaceutical products, and mailboxes with pending patent applications were opened and began to be processed. A few least-developed countries (LDCs) remain exempt from protecting patents until 2021, under the latest extension of the transition period. See World Trade Organization, Extension of the Transition Period Under Article 66.1 for Least-Developed Country Members, Decision of the Council for TRIPS of 11 June 2013, IP/C/64, 12 June 2013.

${ }^{10}$ http://www.ibsa-trilateral.org/ (last accessed 15 March 2016).
} 
Rationalist scholars have focused on the effects of bounded rationality and heuristics in learning (e.g. Simon 1991; Gilardi 2012) whereas scholars looking at ideational factors (e.g. Haas 1992) have paid particular attention to the role of groups of experts and their socialization effects. Bounded rationality refers to the limits faced by individuals in solving complex problems. Given these limitations, individuals (and organizations) are likely to seek heuristics, cognitive shortcuts, which ease the cognitive load of reaching a decision. Under this logic, the fact that complex or controversial policies (such as compulsory licensing) have been successfully enacted, provides incentives for other governments to follow suit. This effect is likely to be stronger if the government that initially enacted the policy is considered to be a least likely case (Gilardi 2012). Another mechanism by which learning processes may take place is through the emergence of epistemic communities or networks of professionals with shared beliefs. These groups can provide governments with policy advice on complex issues: "as demands for such information arise, networks or communities of specialists capable of providing the information emerge and proliferate ... to the extent that an epistemic community consolidates bureaucratic power within national administrations and international secretariats, it stands to institutionalize its influence and insinuate its views into broader international politics" (Haas 1992: 4).

Whereas diffusion through learning occurs as the result of the objective characteristics of policies, emulation follows their normative and socially constructed properties (Gilardi 2012). From this viewpoint, socialization processes occur though repeated interaction, which in turn may induce a change in preferences. In emulation processes, norm entrepreneurs, such as NGOs, play a crucial role in linking domestic debates to international norms (Finnemore/Sikkink 1998). To gain a better understanding of the processes at play, the next sub-section compares the implementation of compulsory licensing in Brazil and India.

\section{Domestic implementation}

While both Brazil and India have been vocal on the international scene and have sought the adoption of mechanisms that ensure the freedom of the state to shape and pursue its own IP policy, their implementation of compulsory licensing schemes and the effective results of these processes are very different. This difference is all the more puzzling when one considers the other similarities between India and Brazil as emerging economies with sufficient industrial capacity and R\&D potential for pharmaceuticals, as well as the prioritized government policies to both further develop the domestic pharmaceutical industry and to fight against HIV/AIDS and other epidemic diseases (Eimer/Lütz, 2010: 136). Also it is noteworthy that both India and Brazil had to amend their domestic laws to bring them into conformity with the TRIPS by 2005.

India, unlike most developing countries, took full advantage of the ten-year transition period to ensure patent protection for pharmaceuticals - which of course allowed it to develop and maintain its massive generic production capacity for drugs that were otherwise on-patent in developed and many developing countries (Abbott/Reichman 2007: 934). Perhaps surprisingly when compared with the active role that India played in the adoption of the 2001 Doha Declaration on Public Health and the 2003 Waiver Decision, it was only at a relatively late stage of the TRIPS implementation activities that India included provisions on compulsory licensing with regard to medicines (Chakraborty/Singhvi 2009). It is also noteworthy in this context that the adopted regime does not provide for either straightforward or swift use of compulsory licensing. The legal terms, as well as the institutional responsibilities are also often unclear.

As has been well documented, while the issuance of compulsory licences in India may in theory be initiated both by the government and the local manufacturers, the numerous procedural and 
substantive hindrances, as well as the specific dynamics of the interplay between governmental and non-governmental agencies and the private sector, severely restrict the opportunity of the state to act proactively (Chaudhuri 2005; Eimer/Lütz 2010). The specificities of the Indian generic drug industry are also such that it tends to innovate either incrementally through minor adaptations of existing pharmaceuticals, which are patentable abroad, or through cooperation with multinational pharmaceutical corporations (Eimer/Lütz 2010). This situation drastically reduces the incentives to lobby for swift and efficient compulsory licensing mechanisms, as well as to make use of the existing schemes. Furthermore, it appears that the majority of Indian R\&D is focused on "western" diseases, such as diabetes and cardiovascular diseases, and tends to neglect local needs. This has been confirmed in reality by the limited practice of compulsory licensing in India, as well as ultimately by the insufficient supply of drugs for those in need, in particular for HIV/AIDS patients (Eimer/Lütz 2010). This situation may have changed following India's decision of 2012 on compulsory licensing for sorafenib, by potentially allowing any number of generics manufacturers to challenge patented medicines so long as they pay royalties to the original manufacturer and seek to lower the price of the drug in order to make it more affordable to Indian patients. ${ }^{11}$

Brazil, on the other hand, and as discussed in more detail below, has chosen a different approach, which has been less onerous and much more efficient. For the grant of compulsory licensing, with regard to local manufacturers, it is sufficient to prove that a patented technology is not locally employed. If the technology is not used in Brazil three years after the sealing of a patent, the Brazilian Patent Office is entitled to issue a compulsory licence, against which no appeal is allowed. Compulsory licences can be directly requested by the government too, and this path appears to be the more important in Brazil. The Ministry of Health can demand a compulsory licence in any situation of emergency, which covers for instance HIV/AIDS, and other epidemic diseases. There are no requirements attached to negotiate with the affected patentee, and the state is well equipped with pharmaceutical laboratories that can actually produce the generic medicines, as well as facilities to engage in the development of improved formulas (Cassier/Correa 2007; Eimer/Lütz 2010). In practice, Brazil has made apt use of compulsory licensing and effectively catered for the supply of medicines its most needy domestic constituencies (Eimer/Lütz 2010).

Against the backdrop of these TRIPS implementation practices and their evolution in India and Brazil, it has been maintained, with good reason, that the variation in the public authorities' regulatory capacity, very often in combination with the varying involvement of the civil society, is decisive for the failure or fulfilment of public health policy goals (Eimer/Lütz 2010). In particular, India is considered to be one of the few developing countries with "access to national or regional experts capable of tailoring the implementation of international IP obligations to foster national development objectives" (Deere Birkbeck 2008: 310). It is thus intriguing that India has taken so long to follow other emerging countries such as Thailand and Brazil in issuing compulsory licences. Furthermore, India's government has not played a relevant role; instead, the private sector has initiated compulsory licensing procedures.

From this overview, it is evident that policies have not converged; on the contrary, compulsory licensing practices have differed significantly. However, this does not mean that coordination or diffusion mechanisms are absent. The next section provides an explanation for the differences in the compulsory licensing regimes of India and Brazil, and seeks to determine whether coordination, learning or emulation processes have acted as drivers for the diffusion of compulsory licensing.

\footnotetext{
${ }^{11} \mathrm{http} / / /$ www.raps.org/focus-online/news/news-article-view/article/1034/in-landmark-ruling-indian-genericsmanufacturer-obtains-compulsory-license.aspx (last accessed 15 March 2016).
} 


\section{Explaining the implementation and diffusion of compulsory licensing in India and Brazil}

India

Positions taken by India on access to health domestically and in multilateral fora have at times lacked coherence. ${ }^{12}$ This is largely the result of domestic dynamics that need to be understood if one is to make sense of Indian IP policies, including compulsory licensing. On the basis of extensive field research carried out during the winter of 2014 in New Delhi, we find that that these dynamics have been driven not only by India's political economy (particularly the role of the different parts of its pharmaceutical industry), but also by its regulatory capacities, ideational aspects, and electoral calculations. The capacity of the Indian state to engage in multilateral negotiations is strongly affected by the need to achieve domestic consensus - particularly between the main ministries concerned: commerce and industry, foreign, finance, agriculture, rural development and communications, as well as information technology (Madan 2013). Each of these ministries has de facto veto power in the fields under its domain and often domestic negotiations become even more cumbersome and complicated than international ones. ${ }^{13}$ Domestic negotiations are long and involve numerous rounds. Until recently, States were not directly involved in these discussions. This tends to create problems once agreements come to be implemented given that States have broad competences in many economic fields. Difficulties in implementing policies have been exacerbated by ongoing fragmentation of the Indian polity, as the rise of regional political parties has raised the profile of some States. This fragmentation is increased by the fact that not all ministries have the same expertise in international negotiations. ${ }^{14}$

As already mentioned, India's compulsory licensing practice has been market- and not governmentdriven. We find this to be largely a result of the importance of the generics industry and divisions between government ministries (see also Eimer/Lütz 2010). While TRIPS posed a challenge to the survival of the thriving generics industry ${ }^{15}$ and triggered strong mobilization and opposition towards stricter patenting requirements, the Council for Scientific and Industrial Research (CSIR) acted as an important counterweight. This reflects, first, the significant increase in patenting taking place in India, and, second, that most Indian patent applications filed abroad were filed by the CSIR (Malhotra

\footnotetext{
${ }^{12}$ The impact of India's conflicting interests in multilateral negotiations can best be observed in the context of the launching of the Development Agenda by Brazil and Argentina at the 2004 WIPO General Assembly. The fact that India was not a co-sponsor of this initiative (even if it later supported it) is puzzling, considering India's long leadership tradition on development issues and great expertise in global IP policy. Fernandes et al. (2012) argue that the breakdown of the traditional alliance between Brazil and India on patent issues resulted from a fundamental divergence between the two countries as to the role of their respective patent systems. This difference made coordination at IBSA problematic and became evident from India's lukewarm support for the Development Agenda. India distanced itself from the negotiations taking place at WIPO and only supported the Development Agenda following the (first) IBSA Summit of September 2006. According to the authors, while Brazil followed a long-held position that considers the need for flexibility in international rules taking into account the development needs of the South; India (at least initially) supported stronger patent protection.

${ }^{13}$ Interview, former Indian trade negotiator, New Delhi, 11 January 2014.

${ }^{14}$ Interview, Indian economist, Jawaharlal Nehru University, New Delhi, 7 January 2014.

${ }^{15}$ This is rather a generalization. The generics industry is not a unitary actor, particularly since consolidation over the past decade has led to big pharmaceutical multinationals buying Indian generics producers.

Some of these acquisitions seem to have resulted in a less vocal position being taken by previously vocal generic drugs actors such as Ranbaxy after being acquired by the Japanese firm, Daichi. Furthermore, some generics producers have also started investing significant amounts in R\&D and have joined strategic alliances with big pharmaceutical corporations. Despite this, from interviews with industry representatives and government officials throughout January and February 2014 it was clear that the generics industry is still an important and influential voice resisting patents. This is particularly the case for drugs that are likely to reap them significant economic benefits such as those related to cancer treatments.
} 
2008). This perspective can be confirmed by the creation of the National Knowledge Commission in 2005 launched by the then Prime Minister Singh. Two of the five key objectives of the Commission were related to IP rights, namely to "improve the management of institutions generating Intellectual Property; [and] improve protection of IPRs and promote knowledge". ${ }^{16}$ This position (which also went against India's traditional stance on patents) was nonetheless strongly opposed and eventually led to a policy reversal. ${ }^{17}$ The mediatization and politicization of the issue of access to medicines and ensuing mobilization of civil society organizations, together with the powerful interests of the pharmaceutical generics industry organized under the Indian Pharmaceutical Alliance and the Indian Drug Manufacturers Association among others, contributed to this policy shift. ${ }^{18}$ Renewed emphasis on flexibility is visible both in multilateral negotiations (particularly India's leading role at the TRIPS Council) and domestically with the implementation of legal reforms such as section 3(d) of the 2005 Indian Patent Act limiting the scope of patentability. There have also been other significant judicial reforms, such as the Right to Information Act passed in October 2005, and an increase in the use of public interest litigation (PIL) allowing NGOs, individuals and other institutions the right to file lawsuits. This also suggests the courts play an increasingly relevant role in domestic politics and in other fields such as trade policy.

To sum up, unlike Brazil (see next section), where the government was central to the enactment of compulsory licensing, in the case of India the government played a more limited role, largely as a result of its conflicting domestic priorities. This in turn allowed other actors such as generic drug manufacturers, civil society organizations, epistemic communities (in particular of legal scholars) and the courts to play a central role in ensuring access to health through several policies and legal initiatives, which included compulsory licensing. This has had the paradoxical effect of making India a policy entrepreneur; after a slow start, it has become a leading jurisdiction implementing IP flexibilities. These innovations, such as the aforementioned section 3(d) of its patent act, are the focus of much attention and debate among scholars and policy-makers in several developing countries such as Brazil and South Africa.

\section{Brazil}

While domestic dynamics have also played a role in Brazil, these have for the most part supported an active role in promoting access to health policies. ${ }^{19}$ This might help explain why in Brazil, unlike India, the government has taken a direct role in requesting compulsory licences. ${ }^{20}$ The lead promoter of access to medicines in Brazil has been its health ministry, together with civil society organizations. While in India the CSIR and the generics industry had largely conflicting interests, in Brazil there was no significant generics industry to speak of but nor was there a powerful actor similar to the CSIR promoting a patent culture. ${ }^{21}$ If one compares the growth of patent filings by India and Brazil during the past decade, it is clear that Brazil has experienced relatively little growth, while the patent filings of India (together with China) have had the highest growth among non-industrialized countries. In 2005, India registered four hundred and three patents in the United States, China five hundred and

\footnotetext{
${ }^{16}$ See press release of Government of India: http://pib.nic.in/newsite/erelease.aspx?relid=9576 (last accessed 15 March 2016).

${ }^{17}$ Interview, academic involved in these discussions, New Delhi, 16 January 2014.

${ }^{18}$ Interview, representative of the Indian Drug Manufacturers Association, New Delhi, 20 February 2014.

${ }^{19}$ Interview, Brazilian trade negotiator, Geneva, 18 September 2012.

${ }^{20}$ Fifteen interviews with diplomats, policy-makers, academics and NGO representatives in Brasilia and Rio de Janeiro, July/August 2014.

${ }^{21}$ The Brazilian Patent Office has perhaps been the most significant actor promoting a patents culture in Brazil, at least throughout the mandate of of its previous head (Jorge Avila). However, despite the tensions between INPI and the Health Ministry (among others) the fact that Brazil has an inter-ministerial group on IP (GIPI) and the strong role played by the Executive Branch means these divisions have been less consequential than has been the case in India.
} 
sixty five, and Brazil only ninety-eight. ${ }^{22}$ In 2013, Brazil filed 769 patent applications in the US, while China filed 15,093 and India some $6,600 .{ }^{23}$ While the pro-market reforms brought by the Collor and Cardoso administration tended to tilt the balance in favour of stronger patenting regulations (in part resulting from significant pressure from the United States), the opposition to these measures was such that this position proved untenable. Furthermore, resisting an expansion of a "patents agenda" is part of a long developmentalist tradition espoused among others by the Brazilian foreign ministry (Itamaraty), which is one of the best staffed and most professional among the emerging countries. Opposition to this developmentalist stance has mainly come from the Brazilian Congress where attempts at reforming the patent legislation to make it more flexible have been blocked for a long time. As Montero (2014) argues, Brazilian executives have a long tradition of overcoming blockages in Congress through Executive Orders (medida provisória); this explains why, despite opposition from the Brazilian Congress, the government has been able to further flexibilities. To sum up, unlike India, political demands and long-held views on development among key ministries in Brazil (particularly the Health Ministry and Itamaraty) have supported government-led efforts to promote IP flexibilities including compulsory licensing.

\section{Coordination, learning or emulation?}

The notable differences between the positions of Brazil and India in international organizations, their divergent domestic practice, and anecdotal evidence obtained from interviews with policy-makers in both countries, all suggest that coordinated intergovernmental efforts have not driven the spread of compulsory licensing practices. Civil society organizations, on the other hand, seem to have played a major role in spreading knowledge and awareness of practices such as compulsory licensing. ${ }^{24}$ The Third World Network and Médecins Sans Frontières (MSF) stand out. These international civil society organisations and transnational activist networks may be considered the main actors through which normative persuasion (and as a result emulation) has taken place. They have also spurred learning by providing information.

There is another relevant and more direct source of contributions to learning processes in the diffusion of compulsory licensing. Experts such as academics, think tanks and legal firms all play relevant roles in policy-making in both countries. Indeed, in India, one way of solving interministerial disputes has been to delegate delicate issues to such actors. In Brazil, relevant fora include the Getulio Vargas Foundation, which has promoted a series of international seminars involving academics and legal practitioners to discuss IP flexibilities. Indian legal practitioners and scholars have also participated actively in these and other similar international academic and professional venues. Legal practitioners and academics have been crucial actors in these epistemic communities; ${ }^{25}$ which also include representatives from major Indian legal firms. India has at least five 'boutique' legal firms that have provided the government with legal capacities and advised and represented the Government of India in WTO disputes (Shaffer/Nedumpara/Sinha 2014). It is not unlikely that these networks of knowledge-based experts (or epistemic communities) influence policy by helping states identify their interests, frame debates, and propose specific policies, including on compulsory licensing. Transnational epistemic communities may influence state policies by pointing out specific issues and as a result "decision makers in one state may, in turn, influence the interests and behaviour of other states, thereby increasing the likelihood of convergent state behaviour and policy coordination informed by the causal beliefs and policy preferences of the epistemic community" (Haas 1992: 4). Our field research found evidence of such a process taking

\footnotetext{
22 Information on US Patent filings is available at www.uspto.gov (last accessed 15 March 2016).

${ }^{23}$ Information on all IP filings worldwide is available at www.ipstats.wipo.int (last accessed 15 March 2016).

${ }^{24}$ Interviews, India WTO Centre, New Delhi, 29 January 2014.

${ }^{25}$ Interviews, legal practitioners, New Delhi, 31 January 2014.
} 
place and suggested some venues (mentioned above) where these learning and emulation processes have occurred.

\section{Conclusions}

The assessment of the Indian and Brazilian experiences as elaborated in this chapter shows diverging approaches in their domestic implementation of TRIPS flexibilities in the domain of compulsory licensing. It also suggests that there has been little or no coordination between the countries and there is no indication that their shared positions on the international scene have led to convergent practices domestically. Domestic and international positions are not always coherent and overall we find IP policies Brazil and India to be in flux. Rather, the national specificities in terms of innovation systems, governmental intervention, industry positioning, and health policies, to name but a few, appear to have shaped the current situation in the laws permitting compulsory licensing and in its actual use. It would however be wrong to assume that no diffusion has occurred and/or is currently under way. Learning does seem to take place. In particular, the existence of an epistemic community involved in policy-making processes suggests that this was a likely venue for the diffusion of compulsory licensing practices. The influence of these networks of experts consisting of academics and legal practitioners seems to have been helped by networks of NGOs (e.g. the Third World Network and MSF) and national media, which contributed to the salience and politicization of the issue of access to health and may have driven emulation processes in addition to learning. To understand and clarify the effects of these diffusion processes, we need to carefully consider the tools available. Compulsory licensing is only one of them and other instruments, for instance Article 3(d) of the Indian Patent Act, may have offered better avenues of IP resistance. One also needs to take into account, as our analysis has shown, the whole spectrum of actors involved, such as networks of experts or even individual legal entrepreneurs, and the interplay between domestic and international positions. Finally, an important theoretical finding of this chapter is that the SouthSouth diffusion of policies relies strongly on informal mechanisms, where individuals within governmental bodies, research institutions, legal firms, or civil society organizations play crucial roles. This is relevant inasmuch as the existing literature has mainly focused on Western diffusion processes, which tend to be much more institutionalized and thus of a different nature. The fact that an alternative type of (South-South) diffusion is taking place is an interesting avenue for further research. 


\section{References}

Abbott, F. M. and Reichman, J. H. (2007) "The Doha Round's Public Health Legacy: Strategies for the Production and Diffusion of Patented Medicines under the Amended TRIPS Provisions," Journal of International Economic Law 10, no. 4: 921-987.

Bass, N. A. (2002-2003) "Implications of the TRIPs Agreement for Developing Countries: Pharmaceutical Patent Laws in Brazil and South Africa in the 21st Century," George Washington International Law Review 34: 191-223.

Beall, R. and Kuhn, R. (2012) "Trends in Compulsory Licensing of Pharmaceuticals Since the Doha Declaration: A Database Analysis", PLoS Med 9, no. 1: e1001154.

Bird, R. C. (2009) "Developing Nations and the Compulsory License: Maximizing Access to Essential Medicines while Minimizing Investment Side Effects," Journal of Law, Medicine and Ethics 37, no. 2: 209-222.

Cassier, M. and Correa, M. (2007) "Intellectual Property and Public Health: Copying of HIV/AIDS Drugs by Brazilian Public and Private Pharmaceutical Laboratories," Electronic Journal of Communication, Information and Innovation in Health 1, no. 1: 83-90.

Chakraborty, S. and Singhvi, A. (2009) "Patent Reform and Compulsory Licensing: A Case Study from India," International Journal of Intellectual Property Management 3: 127-140.

Chan, L.H. (2010) China Engages Global Health Governance: Responsible Stakeholder or SystemTransformer? (Basingstoke: Palgrave Macmillan).

Chaudhuri, S. (2005) "TRIPS and Changes in Pharmaceutical Patent Regime in India," Indian Institute of Management Calcutta Working Paper no. 535.

Cohen, J. (2007) "AIDS Drugs. Brazil, Thailand Override Big Pharma Patents." Science 316, no. 5826: 816.

Correa, C. (2007) Guidelines for the Examination of Pharmaceutical Patents: Developing a Public Health Perspective (Geneva: ICTSD).

Correa, C. M. (2000) Intellectual Property Rights, the WTO and Developing Countries (New York: Zed Books).

Deere Birkbeck, C. (2008) The Implementation Game: The TRIPS Agreement and the Global Politics of Intellectual Property Reform in Developing Countries (Oxford: Oxford University Press).

Drahos, P. (1997) "The Universality of Intellectual Property Rights: Origins and Development", in WIPO Panel Discussion on Intellectual Property and Human Rights (Geneva: World Intellectual Property Organization).

Dwyer, L. (2007) "Patent Protection and Access to Medicine: The Colombian and Peruvian Trade Promotion Agreements," Law and Business Review of the Americas 13, no. 4: 825-857.

Eimer, T. and Lütz, S. (2010) "Developmental States, Civil Society, and Public Health: Patent regulation for HIV/AIDS Pharmaceuticals in India and Brazil," Regulation and Governance 4: 135-153.

Fernandes, L., Garcia, A., Cruz, P. and Willemsens, C. (2012) "Brics Monitor: Brasil e Índia na Agenda Internacional de Patentes", Núcleo de Sistemas de Inovaçao e Governança do Desenvolvimento, BRICS Policy Center.

Finnemore, M. and Sikkink, K. (1998) "International Norm Dynamics and Political Change", International Organization 52, no. 4: 887-917.

Gilardi, F. (2012) "Transnational Diffusion: Norms, Ideas, and Policies", in W. Carlsnaes, T. Risse and B. Simmons, eds, Handbook of International Relations (Thousand Oaks: SAGE): 453-477. 
Goodwin, P. E. (2008) "Right Idea, Wrong Result - Canada's Access to Medicines Regime," American Journal of Law and Medicine 34, no. 4: 567-584.

Haas, P. (1992) "Knowledge, Power, and International Policy Coordination", International Organization 46, no. 1: 1-35.

Helfer, L. R. (2004) "Regime Shifting: The TRIPS Agreement and New Dynamics of International Intellectual Property Lawmaking," Yale Journal of International Law 29, no. 1: 1-83.

Helfer, L. R., Alter, K. J. and Guerzovich, M. F. (2009): "Islands of Effective International Adjudication: Constructing an Intellectual Property Rule of Law in the Andean Community," American Journal of International Law 103: 1-47.

Kapczynski, A. (2008) "The Access to Knowledge Mobilization and the New Politics of Intellectual Property," Yale Law Journal 117: 804-885.

Kapczynski, A. (2009) "Commentary: Innovation Policy for a New Era," Journal of Law, Medicine and Ethics 37, no. 2: 264-268.

Kapczynski, A. (2009a) "Harmonization and Its Discontents: A Case Study of TRIPS Implementation in India's Pharmaceutical Sector," California Law Review 97: 1571-1649.

Kapczynski, A., Park, C. and Sampat, B. (2012) "Polymorphs and Prodrugs and Salts (Oh my!): An Empirical Analysis of 'Secondary' Pharmaceutical Patents," PLoS One 7: e49470.

Lopert, R. and Gleeson, D. (2013) "The High Price of 'Free' Trade: Agreements and Access to Medicines", Journal of Law, Medicine and Ethics 41, no. 1: 199-223.

Lybecker, K. M. and Fowler, E. (2009) "Compulsory Licensing in Canada and Thailand: Comparing Regimes to Ensure Legitimate Use of the WTO Rules," Journal of Law, Medicine and Ethics 37, no. 2: 222-240.

Madan, T. (2013) "What in the World Is India Able to Do? India's State Capacity for Multilateralism", in S. Sidhu, W. Pal, P. Bhanu Mehta and B. Jones, eds., Shaping the Emerging World: India and the Multilateral Order (Washington: Brookings Institution): 95-114.

Maskus, K. E. and Reichman, J. H. (eds.) (2005) International Public Goods and Transfer of Technology Under a Globalized Intellectual Property Regime (Cambridge: Cambridge University Press).

Matthews, D. (2004) "WTO Decision on Implementation of Paragraph 6 of the Doha Declaration on the TRIPS Agreement and Public Health: A Solution to the Access to Essential Medicines Problem?" Journal of International Economic Law 7, no. 1: 73-107.

Mercurio, B. (2006) "TRIPS-Plus Provisions in FTAs: Recent Trends," in L. Bartels and F. Ortino, eds., Regional Trade Agreements and the WTO Legal System (Oxford: Oxford University Press): 215-237.

Mueller, J. M. (2007) “The Tiger Awakens: The Tumultuous Transformation of India's Patent System and the Rise of Indian Pharmaceutical Innovation", University of Pittsburgh Law Review 68, no. 3: 491-641.

Love, J. (2007) "Recent Examples of Compulsory Licensing of Patents," KEI Research Note 2007:2, available at: http://www.keionline.org/content/view/41/1

Panagariya, A. (2002) "Developing Countries at Doha: a Political Economy Analysis", World Economy 25, no. 9: 1205-1233.

Reichman, J. H. (2009) "Comment: Compulsory Licensing of Patented Pharmaceutical Inventions: Evaluating the Options," Journal of Law, Medicine and Ethics 37, no. 2: 247-263.

Reichman, J. H. with C. Hasenzahl (2003) "Non-Voluntary Licensing of Patented Inventions: Historical Perspective, Legal Framework under TRIPS, and an Overview of the Practice in Canada and the 
U.S.A.", UN Conference on Trade and Development [UNCTAD] and International Centre for Trade and Sustainable Development [ICTSD], Project on IPRs and Sustainable Development Issue Paper no. 5.

Sampat, B., Shadlen, K. and Tahir, A. (2013) "Challenges to India's Pharmaceutical Patent Laws", Science 337: 414-415.

Sell, S. K. (2003) Private Power, Public Law: The Globalization of Intellectual Property Rights (Cambridge: Cambridge University Press).

Shaffer, G., Nedumpara, J. and Sinha, A. (2014) "Indian Trade Lawyers and the Building of State Trade-Related Legal Capacity" HLS Program on the Legal Profession Research Paper no. 14; forthcoming in: D. Wilkins, V. Khanna, and D. Trubek, eds. The Indian Legal Profession in the Age of Globalization.

Simon, H. A. (1991) "Bounded Rationality and Organizational Learning", Organization Science 2, no. 1: 125-134.

Sykes, A. O. (2002) "TRIPS, Pharmaceuticals, Developing Countries and the Doha Solution", Chicago Journal of International Law, 3, no. 1: 47-69.

Thomas, J. R. (2014) Compulsory Licensing of Patented Inventions, US Congressional Research Service Report.

Wade, R. H. (2003) "What Strategies Are Viable for Developing Countries Today? The World Trade Organization and the Shrinking of 'Development Space'", Review of International Political Economy 10, no. 4: 621-644.

Watal, J. (2002) Intellectual Property Rights in the WTO and Developing Countries (Boston: Kluwer Law International).

Watal, J. (2015) "Patents: An Indian Perspective", in J. Watal and A. Taubman, eds., The Making of the TRIPS Agreement: Personal Insights form the Uruguay Round Negotiations (Geneva: World Trade Organization), 295-320.

Yeung, H. W. (2005) "Institutional Capacity and Singapore's Developmental State," in H. E. Nesadurai, ed., Globalisation and Economic Security in East Asia: Governance and Institutions (London: Routledge): 85-106.

$\mathrm{Yu}, \mathrm{P}$. (2004) "Currents and Crosscurrents in the International Intellectual Property Regime", Loyola of Los Angeles Law Review 38: 323-444. 